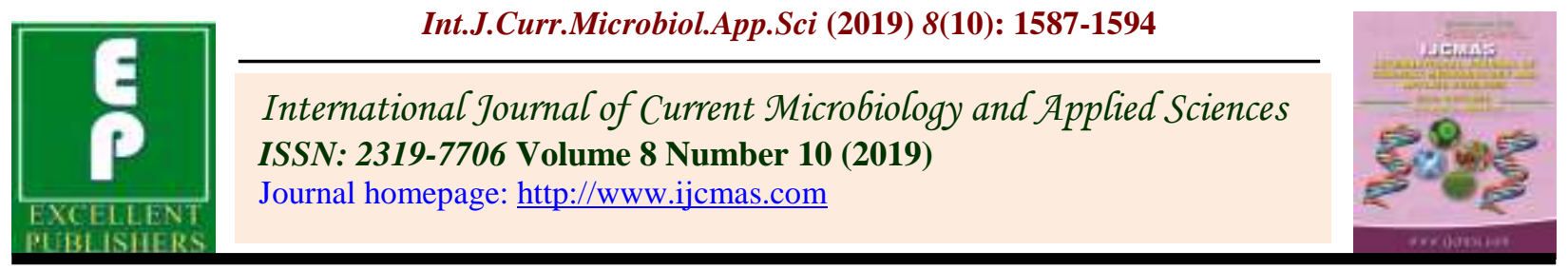

Original Research Article

https://doi.org/10.20546/ijcmas.2019.810.185

\title{
Phenotypic and Biochemical Mechanism of Resistance in Groundnut Genotype against Thrips
}

\author{
V. G. Sonawane, A. M. Misal, P. L. Tavadare*, R. G. Gawali and R. G. Tathe \\ Department of Agriculture Botany, Genetics and Plant Breeding, College of Agriculture, \\ Latur-413512 Maharashtra, India \\ *Corresponding author
}

\begin{tabular}{|l|}
\hline Ke y w o r d s \\
$\begin{array}{l}\text { Thrips, Genotypes, } \\
\text { Phenol, Total sugar, } \\
\text { Leaf water content, } \\
\text { Trichome frequency }\end{array}$ \\
\hline Article Info \\
\hline $\begin{array}{l}\text { Accepted: } \\
\text { 12 September } 2019 \\
\text { Available Online: } \\
\text { 10 October } 2019\end{array}$ \\
\hline
\end{tabular}

\section{Keywords}

Thrips, Genotypes, Phenol, Total sugar, Leaf water content, Trichome frequency

Article Info

Accepted:

12 September 2019

Available Online

(2)

\section{A B S T R A C T}

The field experiment was conducted with 18 groundnut genotypes in a randomized block design during kharif 2016. The study revealed that 5 genotypes from 18 genotypes acted as resistance, 3 as moderately resistance, 4 as moderately susceptible and 6 as susceptible. The genotypes ICGV-86699 (5.30) recorded the lowest population of thrips followed by TG-75(7.30), ICGV-07408 (7.95) and AK-335 (9.50) which shows resistance to the damage of thrips, while moderately resistance reaction was recorded by the genotypes ICGV-7211 (10.55), Dh.241 (10.60) and LGN-1 (8.40). The genotypes ICGV-07038 (11.35), GPBD-4 (11.40), ICGV-00203 (13.45) and Dh. 235 (12.25) showed moderately susceptible reaction. However the genotype which showed the susceptible reaction to thrips JL-24 (21.95) followed byICGV-86031(18.10), LGN-123 (16.90), LGN-176 (15.20) and VriGn-6 (14.75). Phenol content showed significant and negative correlation with thrips population $(r=-0.830)$. Leaf water content $(r=-0.982)$ and trichome frequency $(\mathrm{r}=-0.732)$ revealed negative and significant relationship with thrips population. Total sugar $(r=0.520)$ showed positive and significant relationship with thrips population. Whereas, leaf thickness $(r=0.151)$ showed positive but non-significant.

\section{Introduction}

Groundnut (Arachis hypogaea L.) is an annual legume crop grown as primarily for oilseed, food and feed on a large scale throughout the world. Groundnut is presently cultivated in more than 80 countries worldwide in tropical, sub-tropical and temperate areas located between $40^{0} \mathrm{~N}$ to $40^{\circ} \mathrm{S}$ with world production of 36.45 million tons from an area of 23.95 million ha. In India, it is mainly grown in 11 different states and spread over an area of 4.4 million/ha with production of 7.18 million tons of pods per annum and an average productivity of $1615 \mathrm{~kg} \mathrm{ha}^{-1}$. The groundnut crop in general experience severed serious biotic and abiotic challenge that limits the food yield. Among the several factor 
responsible for low productivity in groundnut. The biggest threat to groundnut cultivation is the damage caused by insect pest. The important insect pests causing damage to the groundnut crop are defoliator and sucking insect pest. Among the sucking insect pest thrips and jassids are the major which causes damage by sucking the sap from tender plant part as a result plant or part dry up. Thrips most of the species are known to be vectors of diseases of groundnut. Thrips mainly feed by lacerating and sucking the sap from leaves is known to transmit groundnut bud necrosis virus. The development of high yielding varieties resistance to thrips is an important strategy to combat low productivity in kharif.

The knowledge of physical barriers present either on the surface or in tissue of plant, make it difficult for feed or causing the host and changes in biochemical constituents of healthy and sucking pest infested leaves of resistance and susceptible cultivars would help in developing the resistance genotype. Hence, the present investigation has been taken up with the biochemical studies for their role in resistance against thrips in groundnut.

\section{Materials and Methods}

The experimental material comprised eighteen genotypes including three checks viz. JL-24, LGN-1 and LGN-123. The genotypes were sown at Oilseed Research Station, Latur during kharif, 2016. The details of genotypes included in experiment are as below.

The experimental material was evaluated at Oilseed Research Station, Latur in Randomized Block Design (RBD) under rainfed (kharif) condition. The sowing was carried out by dibbling at the spacing of $30 \mathrm{~cm}$ and $10 \mathrm{~cm}$ between the rows and plant, respectively. The recommended dose of fertilizer $25 \mathrm{~kg} \mathrm{~N}+50 \mathrm{~kg}$ P2O5 per hectare was applied at time of sowing. All other cultural practices were undertaken to maintain healthy crop except plant protection measures for sucking pest complex.

Several morphological and biochemical characteristics play a major role in plant resistance against thrips, entries belonging to different categories viz., resistant, moderately resistant, susceptible, highly susceptible, with the following methodologies.

\section{Observation on morphological characters}

Observations were made on characters viz., leaf thickness and trichome density of 18 genotypes which were selected on their damage categories. For this top leaves of 30 days old crop in entry were selected and observation are taken. The technique followed for each character was as follows.

\section{Leaf thickness}

The leaf thickness was measured from five leaves of each test entry by using Verniar calipers, and was determined by following formula and expressed in millimeters $(\mathrm{mm})$.

M S D + V S D + L C

Where, M S D = Main Scale Division reading

V S D = Verniar Scale Division read

L C = Least Count

\section{Trichome frequency}

Leaf surface studies were carried out by selecting ten disease free plants of each genotype at 50 days after sowing.

Herbofix impressions were taken from the surface of leaflet on main branch of each genotype by using Fevicol sticker method (Nayeem and Dalvi, 1989). The frequency of 
stomata per mm2 (100x) was worked out in five different microscopic field for each sample.

\section{Biochemical studies}

\section{Leaf water content}

Fresh and dry weights of a unit area of 10 leaflets were measured. Leaf water content was measured by calculating the difference between fresh weight and dry weight.

Leaf water content $=$ Fresh weight - Dry weight

\section{Extraction of phenol content}

One gram of sample was grind in mortal and pestle by adding $10 \mathrm{ml}$ of $80 \%$ ethanol. Homogenate was centrifuged at 10,000 rpm for $20 \mathrm{~min}$ and the supernatant was saved. The extraction was reported and supernatant were pooled.

The ethanol was evaporated by heating $60^{\circ} \mathrm{C}$ on water bath and the volume of residual extract was made to $5 \mathrm{ml}$ by adding distilled water. The extract was again centrifuge at $10,000 \mathrm{rpm}$ for $20 \mathrm{~min}$. supernatant was collected and used for colour development.

\section{Colour development}

The aliquot $(0.2 \mathrm{ml})$ in triplicate were taken in the test tube and the volume was adjusted to 3 $\mathrm{ml}$ in each tube $0.5 \mathrm{ml}$ folin-ciocaltea reagent was added.

After three min $2 \mathrm{ml}$ of 20 per cent $\mathrm{Na}_{2} \mathrm{CO}_{3}$ solution was added and mixed thoroughly.

The test tubes were placed in boiling water bath for one minute. After cooling the test tube, the absorbance was measured against blank.
Extraction of total sugars (by anthron method)

Weight $100 \mathrm{mg}$ of the sample into a boiling tube. Hydrolyze by keeping it in a boiling water bath for three hours with $5 \mathrm{ml}$ of $2.5 \mathrm{~N}$ $\mathrm{HCl}$ and cool to room temperature. Neutralise it with solid sodium carbonate until the effervescence ceases. Make it up the volume to $100 \mathrm{ml}$ and centrifuge. Collect the supernatant and take 0.5 and $1 \mathrm{ml}$ aliquots for analysis. Prepare the standards by taking 0 , $0.2,0.4,0.6$, and $0.8 \& 1 \mathrm{ml}$ of the working standard. 0 serve as blank. Make up the volume to $1 \mathrm{ml}$ in all tube including the sample tubes by adding distill water.

Then add $4 \mathrm{ml}$ of anthrone reagent. Heated for 8 minute in a boiling water bath. Cool rapidly $\&$ read the green to dark green colour at 630 nm. Draw a standard graph by plotting concentration of the standard on the $\mathrm{X}$ axis verses absorbance on the $\mathrm{Y}$ axis. From the graph calculated the amount of carbohydrate present in the tube sample tube.

Calculation-Amount of carbohydrates present in $100 \mathrm{mg}$ of the sample $=$ (mg of glucose/ volume of test sample) $* 100$

\section{Results and Discussion}

Eighty groundnut varieties were screened against thrips under field condition during kharif 2016 season. The average population of the genotypes ICGV-86699 (5.30) recorded the lowest population of thrips followed by TG-75 (7.30), ICGV-07408 (7.95) and AK335 (9.50) thrips per terminal bud with injury damage score of 2 which shows the above genotypes were resistance to the damage of thrips, while moderately resistance reaction was recorded by the genotypes viz. ICGV7211 (10.55), Dh.241 (10.60) and LGN-1 (8.40) with damage score of 3 which shows that the genotypes were moderately resistance. 
The genotypes viz. ICGV-07038 (11.35), GPBD-4 (11.40), ICGV-00203 (13.45) and Dh.235 (12.25) showed moderately susceptible reaction having the damage score 4.However the genotype which showed the susceptible reaction to thrips JL-24 (21.95) followed by ICGV-86031(18.10), LGN-123 (16.90), LGN-176 (15.20) and VriGn-6 (14.75) with damage score 5.

\section{Leaf thickness (mm)}

The leaf thickness in different categories varied from 0.27 to $0.49 \mathrm{~mm}$. Resistance entries viz., ICGV-86699 (0.27mm), TG-75 (0.41mm), ICGV-07408 (0.31mm), AK-335 $(0.40 \mathrm{~mm})$ and $\mathrm{LGN}-184(0.31 \mathrm{~mm})$ shows variation in leaf thickness. The relationship between leaf thickness and thrips population were positive and non-significant.

Leaf thickness exhibits positive and nonsignificant association with thrips incidence $(r=0.151)$. Leaf thickness exhibits positive and non-significant association with thrips incidence. These result indicating that no role of leaf thickness with thrips population. Similar result was reported by Naik and Somashekhar (2015) (Table 1-4).

Table.1 List of groundnut genotypes

\begin{tabular}{|c|c|c|}
\hline Sr.No. & Genotype & Pedigree \\
\hline $\mathbf{1}$ & TG-75 & TG-26 x R. 9227 \\
\hline $\mathbf{2}$ & GPBD-4 & - \\
\hline $\mathbf{3}$ & ICGV-7211 & ICGV 98191 x ICGV-0005 \\
\hline $\mathbf{4}$ & AK-335 & Selection from TG- 36 B \\
\hline $\mathbf{5}$ & ICGV-07038 & JL-24 x ICGV-99032 \\
\hline $\mathbf{6}$ & LGN-184 & Selection form VG-9816 \\
\hline $\mathbf{7}$ & Vri Gn-6 & GPBD-4 x Dh.46 \\
\hline $\mathbf{8}$ & Dh.241 & ICGV-94118 x ICGV-93427 \\
\hline $\mathbf{9}$ & ICGV-00203 & CSMG 184.1 x TG-37 \\
\hline $\mathbf{1 0}$ & LGN-176 & GPBD-4 x R.8808.6 \\
\hline $\mathbf{1 1}$ & Dh.235 & - \\
\hline $\mathbf{1 2}$ & ICGV-86699 & x ICGS-76 \\
\hline $\mathbf{1 3}$ & ICGV-07408 & (ICGV-87446 x (ICGV-87290 x ICGV-8746) x ICGS-44 \\
\hline $\mathbf{1 4}$ & ICGV-86031 & - \\
\hline $\mathbf{1 5}$ & R-2001-2 & JL- 24 X NcAc -17090 \\
\hline $\mathbf{1 6}$ & LGN-1 (c) & Selection from EC 94943 \\
\hline $\mathbf{1 7}$ & JL-24 (c) & ICGV- 86123 x ICGV - 97153 \\
\hline $\mathbf{1 8}$ & LGN-123 (c) & \\
\hline & &
\end{tabular}


Table.2 Mean performance of groundnut genotype for morph-biochemical character

\begin{tabular}{|c|c|c|c|c|c|c|c|c|c|}
\hline $\begin{array}{l}\text { Sr. } \\
\text { No. }\end{array}$ & Genotypes & $\begin{array}{l}\text { Phenol } \\
\text { content }\end{array}$ & SMCR & $\begin{array}{c}\text { Total } \\
\text { sugar }\end{array}$ & $\begin{array}{c}\text { Leaf water } \\
\text { content }\end{array}$ & $\begin{array}{c}\text { Leaf } \\
\text { thickness }\end{array}$ & $\begin{array}{l}\text { Trichome } \\
\text { frequency }\end{array}$ & $\begin{array}{c}\text { Thrips } \\
\text { incidence }\end{array}$ & $\begin{array}{l}\text { Pod yield } \\
\text { per plant }\end{array}$ \\
\hline 1 & TG-75 & 0.33 & 24.25 & 1.40 & 65.20 & 0.41 & 9.55 & 7.30 & 14.70 \\
\hline 2 & GPBD-4 & 0.26 & 24.45 & 1.50 & 62.00 & 0.38 & 7.70 & 11.40 & 16.27 \\
\hline 3 & ICGV-7211 & 0.24 & 18.40 & 2.95 & 59.70 & 0.49 & 6.60 & 10.55 & 15.27 \\
\hline 4 & AK-335 & 0.30 & 19.00 & 2.85 & 59.00 & 0.40 & 10.65 & 9.50 & 12.68 \\
\hline 5 & ICGV-07038 & 0.24 & 28.10 & 7.55 & 52.20 & 0.35 & 8.35 & 11.35 & 21.95 \\
\hline 6 & LGN-184 & 0.34 & 25.95 & 1.50 & 57.90 & 0.31 & 8.60 & 9.65 & 19.78 \\
\hline 7 & Vri Gn-6 & 0.21 & 20.65 & 2.65 & 51.20 & 0.45 & 6.55 & 14.75 & 17.15 \\
\hline 8 & Dh.241 & 0.26 & 19.70 & 2.70 & 52.60 & 0.37 & 5.25 & 10.60 & 15.68 \\
\hline 9 & ICGV-00203 & 0.20 & 34.25 & 4.65 & 51.10 & 0.43 & 8.45 & 13.45 & 24.15 \\
\hline 10 & LGN-176 & 0.22 & 28.40 & 3.45 & 48.70 & 0.33 & 5.85 & 15.20 & 24.95 \\
\hline 11 & Dh.235 & 0.22 & 12.10 & 2.20 & 53.90 & 0.39 & 5.85 & 12.25 & 16.69 \\
\hline 12 & ICGV-86699 & 0.37 & 29.40 & 1.90 & 65.00 & 0.27 & 11.65 & 5.30 & 22.05 \\
\hline 13 & ICGV-07408 & 0.27 & 26.70 & 1.45 & 60.30 & 0.31 & 7.50 & 7.95 & 23.80 \\
\hline 14 & ICGV-86031 & 0.22 & 21.65 & 2.65 & 52.20 & 0.39 & 6.50 & 18.10 & 11.40 \\
\hline 15 & R-2001-2 & 0.27 & 24.10 & 1.95 & 49.90 & 0.34 & 8.05 & 13.80 & 16.60 \\
\hline 16 & LGN-1 C & 0.33 & 18.35 & 3.45 & 62.50 & 0.30 & 11.10 & 8.40 & 12.71 \\
\hline 17 & JL-24C & 0.21 & 16.85 & 6.60 & 46.10 & 0.35 & 5.50 & 21.95 & 16.00 \\
\hline \multirow[t]{5}{*}{18} & LGN-123 C & 0.24 & 27.85 & 4.20 & 50.80 & 0.30 & 5.55 & 16.90 & 22.15 \\
\hline & Mean & 0.265 & 23.34 & 3.008 & 55.57 & 0.36 & 7.73 & 12.13 & 17.99 \\
\hline & S. E. \pm & 0.017 & 0.263 & 0.025 & 2.212 & 0.021 & 0.415 & 0.858 & 1.146 \\
\hline & C. D. at $5 \%$ & 0.053 & 0.786 & 0.766 & 6.602 & 0.063 & 1.240 & 2.561 & 3.420 \\
\hline & C. V. \% & 9.512 & 1.597 & 11.75 & 5.631 & 8.210 & 7.597 & 10.004 & 9.005 \\
\hline
\end{tabular}


Table.3 Reaction of groundnut genotypes against thrips damage

\begin{tabular}{|c|c|c|c|}
\hline \multirow{2}{*}{$\begin{array}{c}\text { Sr. } \\
\text { No. }\end{array}$} & \multirow{2}{*}{ Genotypes } & \multicolumn{2}{|c|}{ Thrips } \\
\cline { 3 - 4 } & & $\begin{array}{c}\text { Populatio } \\
\text { n }\end{array}$ & $\begin{array}{c}\text { Damage } \\
\text { score }\end{array}$ \\
\hline $\mathbf{1}$ & TG-75 & 7.30 & 2 \\
\hline $\mathbf{2}$ & GPBD-4 & 11.40 & 4 \\
\hline $\mathbf{3}$ & ICGV-7211 & 10.55 & 3 \\
\hline $\mathbf{4}$ & AK-335 & 9.50 & 2 \\
\hline $\mathbf{5}$ & ICGV-07038 & 11.35 & 4 \\
\hline $\mathbf{6}$ & LGN-184 & 9.65 & 2 \\
\hline $\mathbf{7}$ & Vri Gn-6 & 14.75 & 5 \\
\hline $\mathbf{8}$ & Dh.241 & 10.60 & 3 \\
\hline $\mathbf{9}$ & ICGV-00203 & 13.45 & 4 \\
\hline $\mathbf{1 0}$ & LGN-176 & 15.20 & 5 \\
\hline $\mathbf{1 1}$ & Dh.235 & 12.25 & 4 \\
\hline $\mathbf{1 2}$ & ICGV-86699 & 5.30 & 2 \\
\hline $\mathbf{1 3}$ & ICGV-07408 & 7.95 & 2 \\
\hline $\mathbf{1 4}$ & ICGV-86031 & 18.10 & 5 \\
\hline $\mathbf{1 5}$ & R-2001-2 & 13.80 & 5 \\
\hline $\mathbf{1 6}$ & LGN-1 @ & 8.40 & 3 \\
\hline $\mathbf{1 7}$ & JL-24@ & 21.95 & 5 \\
\hline $\mathbf{1 8}$ & LGN-123 $@$ & 16.90 & 5 \\
\hline & & & \\
\hline
\end{tabular}

Table.4 Reaction of groundnut genotypes against thrips damage under field condition

\begin{tabular}{|c|c|c|}
\hline Genotypes & $\begin{array}{c}\text { Thrips damage } \\
\text { score }\end{array}$ & Reactions \\
\hline None & 1 & Immune \\
\hline $\begin{array}{c}\text { ICGV-86699, ICGV-07408, TG- } \\
\text { 75, AK-335, LGN-184 }\end{array}$ & 2 & Resistance \\
\hline ICGV-7211, Dh.241, LGN-1 C & 3 & $\begin{array}{c}\text { Moderately } \\
\text { resistance }\end{array}$ \\
\hline ICGV-07038, GPBD-4, ICGV- \\
$\mathbf{0 0 2 0 3 , \text { Dh.235 }}$ & 4 & $\begin{array}{c}\text { Moderately } \\
\text { susceptible }\end{array}$ \\
\hline $\begin{array}{c}\text { Vri Gn-6, LGN-176, ICGV- } \\
\text { 86031, R-2001-2, JL-24C, LGN- } \\
\mathbf{1 2 3} \text { C }\end{array}$ & 5 & $\begin{array}{c}\text { Susceptible } \\
\text { None }\end{array}$ \\
\hline
\end{tabular}




\section{Trichome frequency or density}

Trichome frequency per $\mathrm{mm}^{2}$ on surface of leaves ranged From 5.25 to11.65 with over all mean of 7.73. The genotypes viz., ICGV86699 (11.65), LGN-1 (11.10), AK-335 (10.65), and TG-75 (9.55) recorded maximum number trichome on surface of leaves. The relationship between trichome frequency and thrips and jassid population were positive and significant.

Trichome frequency were negative and significant association with thrips incidence $(r=-0.732)$. Trichome frequency was negative and significant with thrips incidence and jassid incidence. The lower incidence of thrips occurred due to high leaf trichomes. Similar results were reported by Dwivedi et al., (1986) on close association between resistance to thrips and dark green leaf colour, leaf wax and hairy (Trichomes) characters in peanut cultivar ICGV-86031 and Ramakrishna Raoet al., (2015).

\section{Leaf water content (\%)}

Leaf water content varied from 46.10 to 65.20 per cent with overall mean 55.70 per cent. Higher leaf water content recorded in TG-75 $(65.20 \%)$ followed by ICGV-86699 (65.0\%), LGN-1 (62.50), GPBD-4 (62.0\%), ICGV07408 (60.30) and ICGV-7211 (59.70). the leaf water content exhibit negative and significant correlation against thrips.

Leaf water content shows negative and significant correlation with thrips incidence $(\mathrm{r}=-0.982)$. Similar result found by Gadadet al., (2014).

\section{Total phenol content $(\mathrm{mg} / \mathrm{g})$}

The mean phenol content values ranged between 0.20 and $0.37 \mathrm{mg} / \mathrm{g}$ with mean of $0.26 \mathrm{mg} / \mathrm{g}$. The high phenol content genotypes shows lower incidence of thrips viz., ICGV86699 (0.37mg), LGN-184 (0.34mg), LGN-1 $(0.33 \mathrm{mg})$, TG-75 $(0.33 \mathrm{mg})$ per gram of leaf sample. However, lower quantities were noticed in susceptible genotype viz., LGN-123 $(0.24 \mathrm{mg}), \mathrm{JL}-24(0.21 \mathrm{mg})$ per gram of leaf samples. Phenolic content of selected varieties were quantified in the present study and correlation between thrips population and phenol content was negative and significant $(\mathrm{r}=$ -0.832). Phenol content is extremely abundant plant allelochemicals often associated with feeding deterrence or growth inhibition of herbivores. The present findings of decreased intensity of thrips attack with increase in phenol content in the genotypes. This result is in confirmation with the finding of Kandakoor et al., (2013), Gadad et al., (2014), Ramakrishna Rao et al., (2015), Naik and Somashekhar (2015).

\section{Total sugar $(\mathrm{mg} / \mathrm{g})$}

The mean performance of total sugar revealed that the range was between 1.4 to $7.55 \mathrm{mg}$ with mean of $3.08 \mathrm{mg}$ per gram of leaf sample.

The highest quantities were noticed in susceptible genotypes viz., ICGV-07038 (7.55 $\mathrm{mg} / \mathrm{g})$, JL-24 (6.60 mg/g), ICGV-00203(4.65 $\mathrm{mg} / \mathrm{g})$, LGN-123 (4.20 mg/g). Total sugar content shows that positively correlated with thrips population $(r=0.520)$, highest quantities were noticed in susceptible genotypes. These result are in conformed with Kandakoor et al., (2013), Gadad et al., (2014), Ramakrishna Rao et al., (2015), Naik and Somashekhar (2014).

\section{References}

Dwivedi, S. L., Amin, R., Nigam, S. N., Nagabhushanam, G. V. S., Rao, V. R. and Gibbons, R. W. 1986. Genetic 
analysis of trichome character association with resistance to jassid (Empoascakerri Pruthi) in peanut. Peanut Science, 13 (1): 15-18.

Gadad, H., Hedge, M. and Balikai, R. A. 2014. Screening and biochemical analysis for resistance against groundnut thrips. Biochem. Cell. Arch., 14(1):145-149.

Hemant Kumar, M. 2004. Genetic analysis of morphological, physiological and biochemical characters in relation to yield and quality in groundnut (Arachis hypogaea L.). Ph.D.thesis submitted to N.G. Ranga Agricultural University, Hyderabad.

Jayalakshmi, V., Reddy, C.R., Reddy, P.V. and Reddy, G.L. 2000. Character association among morphophysiological attributes in parental genotypes and groundnut hybrids. Legume Res., 23(2): 102-105.

Kahate, N.S., Toprope, V.N. and Gadakh, S.S. 2014. Correlation and pathanalysis for yield, morphology and biochemical traits in groundnut (Arachis hypogea L.) BIOINFOLET 11(3B): $868-870$.

NaikOnkara, S., Somashekhar. 2015. Phenotypic and biochemical mechanism of resistance in groundnut genotype and varieties against leafhopper and thrips. Ecology, environment and Conservation paper., 21(1): 535-543.
Naik, O. S., 2005, Studies on sucking insect pest of groundnut. M. Sc. (Agri.) Thesis, Univ. Agric. Sci., Dharwad.

Ramakrishna Roa, A., Murlikrshna, T., John, K., Sudhakar, P., Devaki, K. and Rajendra Prasad, P.B., 2015, Influence of morphological traits on resistance of groundnut genotypes. African J Agri Research 10 (4) 250-263.

RangaRoa, G.V. and Wightman, J.A., 1997, Techniques for screening groundnut genotypes for resistance to pests, Spodoptera litura (F.) in India. Proceedings of The National Scientists Forum on Spodoptera litura ICRISAT, Patancharu. Pp. 68-75.

Rao, A. R., John, K., Muralikrishna, T., Sudhakar, P., Devaki K. and Rajendraprasad P. 2015 Biochemical basis of resistance to thrips in groundnut (Arachis hypogaeaL.). Current Biotic., 8(4): 382-394.

Somashekhar, Onkara, N. S. and Patil, V. B., 2003, Mechanism of resistance in groundnut cultivars against thrips. Proceedings of National Symposium on Frontier Areas of Entomological research, November 5-7, pp. 401-402.

Subhash, B., K, H., khader Khan, G., BasanaGowda, Chakravarthy,A. K., Ashok Kumar, C. T. and Venkatararavana, P., 2014, J. Environmental Biology, Vol. 35, 675681.

\section{How to cite this article:}

Sonawane, V. G., A. M. Misal, P. L. Tavadare, R. G. Gawali and Tathe, R. G. 2019. Phenotypic and Biochemical Mechanism of Resistance in Groundnut Genotype against Thrips. Int.J.Curr.Microbiol.App.Sci. 8(10): 1587-1594. doi: https://doi.org/10.20546/ijcmas.2019.810.185 